\title{
EKSPERIMENTASI MODEL PEMBELAJARAN \\ KOOPERATIF TIPE THREE STEPS INTERVIEW (TSI) DAN THINK PAIR SHARE (TPS) PADA MATERI FUNGSI DITINJAU DARI KECERDASAN LOGIS MATEMATIS SISWA KELAS VIII SMP NEGERI SE-KABUPATEN KLATEN TAHUN PELAJARAN 2015/2016
}

\author{
Heni Septi Rahayu ${ }^{1}$, Budiyono $^{2}$, Budi Usodo ${ }^{3}$ \\ ${ }^{1,2,3}$ Prodi Magister Pendidikan Matematika, FKIP Universitas Sebelas Maret Surakarta
}

\begin{abstract}
The purpose of this study was to determine the effect of the learning models TSI, TPS, and direct learning model on mathematics learning achievement viewed from the students logical mathematical intelligence. The type of this study was quasi experimental study with $3 \times 3$ factorial design. The population were the eighth-grade students of junior high schools in Klaten Regency in the academic year of 2015/2016. Instruments used for data collection were mathematics achievement test and logical mathematical intelligence test. The data analysis technique used was the two-way ANAVA with unbalanced cell. Based on the hypothesis, it was concluded as follows. 1) The mathematics learning achievement of TSI was better than TPS and direct learning model, the mathematics learning achievement of TPS was better than direct learning model. 2) The mathematics learning achievement of the students with high logical mathematics was better than the students with average and low logical mathematics, the students with average logical mathematics was better than the students with low logical mathematics. 3) The students with high logical mathematics who were treated by TSI, TPS, direct learning models had the same mathematics learning achievement, students with low logical mathematics treated with TPS and TSI has the same result for both models and was better direct learning model, the students who were treated by TPS learning model was better than direct learning model, the students with low logical mathematics who were treated by TSI was same as TPS and was better than direct learning model. 4) In TSI learning model, the mathematics learning achievement of students with high logical mathematic was better than the students with both average and low logical mathematics, the students with average logical mathematic was better than students with low logical mathematics, in TPS learning model, the students with high logical mathematics was same as the achievement of students with average logical mathematics and was better than the students with low logical mathematic, in direct learning model, the students with high logical mathematics was better than the students with average and low logical mathematics, the students with average logical mathematics was same as the students with low logical mathematics.
\end{abstract}

Keywords: Three Steps Interview, Think Pair Share Direct Learning Model, Logical Mathematical Intelligence.

\section{PENDAHULUAN}

Pendidikan matematika memiliki peran yang sangat penting dalam keberhasilan pengembangan mutu pendidikan di Indonesia karena matematika merupakan ilmu dasar yang digunakan secara luas dalam berbagai bidang kehidupan. Berdasarkan hal tersebut, matematika dianggap sebagai ilmu yang sangat penting dan diajarkan hampir di semua jenjang pendidikan, mulai dari sekolah dasar, sekolah menengah hingga perguruan tinggi. Permasalahan yang dihadapi dalam proses pembelajaran matematika saat ini adalah masih rendahnya prestasi belajar siswa. Selain itu banyak orang juga beranggapan 
bahwa matematika sebagai mata pelajaran yang sulit untuk dikuasai oleh sebagian besar siswa, sehingga matematika merupakan mata pelajaran yang kurang disenangi. Pendapat ini didukung oleh E.T. Ruseffendi (1991:15) yang menyatakan bahwa matematika (ilmu pasti) bagi anak-anak dan secara umum merupakan mata pelajaran yang tidak disenangi, dan atau mata pelajaran yang dibenci. Hal ini disebabkan karena mereka menganggap bahwa matematika rumit dan membingungkan.

Berdasarkan data dari Badan Standar Nasional Pendidikan (BSNP) dari data PAMER UN 2013/2014 dapat dilihat nilai rata-rata hasil Ujian Nasional (UN) Matematika SMP Negeri tahun pelajaran 2013/2014 di Kabupaten Klaten hanya 5,24, lebih rendah jika dibandingkan rata-rata di Provinsi Jawa Tengah yaitu 5,63 dan di tingkat nasional yaitu 6,10. Salah satu materi yang sulit bagi siswa SMP adalah materi tentang fungsi. Berdasarkan data daya serap (Pamer UN 2013/2014), persentase penguasaan siswa SMP di Kabupaten Klaten dalam menyelesaikan masalah yang berkaitan dengan fungsi yaitu $48,64 \%$ dan ternyata persentase tersebut masih rendah dibandingkan dengan persentase daya serap materi garis-garis istimewa pada segitiga yaitu sebesar 56,72\% dan masih lebih rendah juga dibanding persentase daya serap materi teorema Phythagoras yaitu sebesar 95,57\%. Dengan demikian, dapat disimpulkan sebagian besar siswa SMP di Kabupaten Klaten mengalami kesulitan dalam menyelesaikan soal-soal yang berkaitan dengan materi fungsi.

Fungsi merupakan salah satu materi matematika yang termasuk dalam materi aljabar, adalah materi prasyarat yang mudah untuk dipahami karena bersifat esensial dan prosedural. Kendala yang masih banyak dirasakan oleh para guru dalam mengajarkan fungsi antara lain yang berkaitan dengan pemahaman konsep. Adapun hasil penelitian yang ditunjukkan Dede dan Soybas (2011) bahwa, "students at every levels have some difficulties in elgebraic equations as well as in understanding concept of function, and in determining the relationship between them". Dapat diartikan bahwa, beberapa siswa pada setiap tingkat memiliki beberapa kesulitan dalam persamaan-persamaan aljabar seperti dalam memahami konsep fungsi, dan menentukan hubungan diantara persamaanpersamaan dan konsep fungsi.

Menurut Nini Subini (2012: 85) pencapaian tinggi rendahnya prestasi belajar siswa dipengaruhi oleh beberapa faktor, yaitu internal dan eksternal. Salah satu faktor eksternal yang mungkin mempengaruhi rendahnya prestasi belajar matematika yaitu belum semua guru mampu memilih dan menerapkan model pembelajaran yang tepat dan sesuai dengan tujuan pembelajaran untuk suatu kompetensi tertentu. Salah satu contohnya adalah dalam pembelajaran matematika di sekolah masih menggunakan model pembelajaran langsung yang menempatkan guru sebagai pusat pembelajaran. Dalam 
model pembelajaran langsung, siswa hanya menerima informasi selama proses pembelajaran berlangsung, kegiatan pembelajaran didominasi oleh guru. Guru menyampaikan materi dan memberikan contoh soal sedangkan siswa hanya mendengarkan, meniru pola-pola yang diberikan oleh guru, dan mencontoh cara menyelesaikan soal. Hal ini menyebabkan siswa cenderung kurang aktif dalam proses pembelajaran karena tidak diberi kesempatan untuk menemukan sendiri suatu konsep yang mereka pelajari, sehingga pembelajaran yang belangsung kurang bermakna, pengetahuan dan konsep yang esensial dari materi tidak didapatkan sebagai akibat dari pola belajar yang cenderung menghafal dan menirukan apa yang telah diberikan guru.

Berdasarkan kondisi di atas, diperlukan upaya guru dalam menerapkan inovasi pembelajaran untuk meningkatkan prestasi belajar siswa. Salah satunya adalah dengan menerapkan pembelajaran kooperatif dalam pembelajaran. Ellis dan Fouts dalam Cheng (2011 : 79) mengungkapkan bahwa "Cooperative learning, which is hailed as the "most important and most successful teaching method reform in the last decade", yang artinya model pembelajaran kooperatif merupakan model pembelajaran yang paling penting dan paling berhasil pada masa ini. Selain itu, pembelajaran kooperatif adalah salah satu inovasi pembelajaran yang membuat siswa belajar lebih aktif, berpikir lebih kritis, dan mampu berinteraksi dengan siswa yang lainnya serta mampu mengembangkan kecerdasan yang dimilikinya. Hal ini sejalan dengan Koppenhaver dan Shrader (2003) bahwa,

Cooperative learning aims at learner-centered learning and claims to increase the level of understanding and reasoning, develop critical thingking, and increase the accuracy of long-term retention.

Maknanya, tujuan pembelajaran kooperatif adalah pembelajaran yang berpusat pada siswa dan menekankan pada peningkatkan tingkat pemahaman dan pemikiran, mengembangkan cara berpikir yang kritis, dan meningkatkan ketepatan ingatan jangka panjang. Hasil penelitian Walmsley dan Muniz (2003) menyatakan model pembelajaran kooperatif mempunyai banyak efek yang positif dalam kelas matematika apabila diterapkan dengan tepat. Hasil tersebut sejalan dengan penelitian Zakaria et al. (2010) menunjukkan bahwa pembelajaran kooperatif meningkatkan prestasi belajar siswa pada mata pelajaran matematika. Pada model pembelajaran kooperatif mempunyai beberapa tipe seperti model pembelajaran kooperatif Three Steps Interview (TSI) dan Think Pair Share (TPS).

Model pembelajaran kooperatif TSI atau disebut juga dengan three problemsolving merupakan model pembelajaran yang efektif digunakan untuk memecahkan masalah (problem solving). Model TSI ini memiliki tiga tahapan inti dalam menyelesaikan masalah, yaitu (share) pemikirannya, (question) bertanya, dan (take a 
note) membuat catatan (Suparman, 2001:9). Selain itu, pada model ini siswa dituntut untuk menggunakan kemampuan kognitif pada tingkat berpikir aplikasi, analisis, sintesis, dan evaluasi. Pada model pembelajaran TSI, siswa melakukan kegiatan tanya jawab secara berpasangan. Pertama satu arah, kemudian mereka bertukar peran sebagai penanya dan penjawab. Siswa juga dapat bertukar informasi dengan penanya tentang apa yang telah mereka pelajari (Liang, 2002). Model ini mengandalkan kerjasama antar siswa dan terdapat tanggung jawab perseorangan. Selain itu, model ini menempatkan siswa dalam kelompok belajar yang beranggotakan empat orang dengan kemampuan yang berbedabeda.

Model pembelajaran TPS merupakan model pembelajaran kooperatif terstruktur. Pelaksanaan kegiatannya mengandalkan kerjasama antar siswa dalam memecahkan masalah. Dalam pelaksanaan model TPS guru menyajikan materi secara klasikal, memberikan persoalan kepada siswa dan siswa berkelompok secara berpasangan sebangku-sebangku (think-pairs), kemudian presentasi di depan kelas (share). Dengan adanya "pasangan" siswa tidak akan merasa malu dan mereka tidak akan takut salah karena mereka merasa dapat berbagi rasa malu yang mungkin timbul, selain itu model pembelajaran ini juga dirancang untuk mempengaruhi pola interaksi siswa karena pada model pembelajaran ini siswa dituntut untuk berdiskusi dan memberi kesempatan kepada setiap anggotanya untuk memberikan ide dan mempertimbangkan jawaban yang tepat sebelum disampaikan di depan kelas. Dengan kata lain, secara tidak langsung dapat menumbuhkan keberanian siswa dalam berkomunikasi di depan kelas. Model pembelajaran kooperatif tipe TPS merupakan cara yang efektif untuk membuat variasi suasana pola diskusi kelas.

Faktor eksternal lain yang diduga dapat mempengaruhi prestasi belajar siswa, salah satunya adalah kecerdasan siswa. Kecerdasan yang dimaksud adalah kecerdasan majemuk yang dikemukakan oleh Gardner. Gardner (2007) mendefinisikan kecerdasan logis matematis sebagai kemampuan untuk analyze problems (menganalisis masalah), detecting patterns (menyusun pola), perform mathematical calculations (menyelesaikan perhitungan matematis), scientific reasoning and deduction (penalaran ilmiah dan deduktif), understands relationship between cause and effect toward a tangible outcome or result (memahami hubungan antara sebab dan akibat pada hasil yang nyata). Kecerdasan logis matematis ini berpengaruh pada proses pembelajaran matematika.

Tujuan penelitian ini adalah untuk mengetahui: 1) diantara model pembelajaran TSI, model pembelajaran TPS dan model pembelajaran langsung, manakah yang memberikan prestasi belajar matematika lebih baik pada materi fungsi; 2) diantara siswa yang mempunyai kecerdasan logis matematis tinggi, sedang,dan rendah, manakah yang 
prestasi belajar matematikanya lebih baik pada materi fungsi; 3) pada masing-masing tingkat kecerdasan logis matematis (tinggi, sedang dan rendah), manakah yang prestasi belajar matematikanya lebih baik antara siswa yang diberi pembelajaran dengan model pembelajaran TSI, model pembelajaran TPS atau model pembelajaran langsung; 4) pada masing-masing model pembelajaran (TSI, TPS dan langsung), manakah yang prestasi belajar matematikanya lebih baik antara siswa yang mempunyai kecerdasan logis matematis tinggi, sedang atau rendah.

\section{METODE PENELITIAN}

Penelitian ini termasuk penelitian eksperimental semu yang dirancang dengan desain faktorial $3 \times 3$. Populasinya adalah seluruh siswa kelas VIII SMP Negeri di Kabupaten Klaten, dan sampelnya diambil dengan teknik stratified cluster random sampling. Penelitian ini dilakukan di SMP Negeri 1 Klaten, SMP Negeri 1 Gantiwarno, dan SMP Negeri 6 Klaten yang masing-masing diambil tiga kelas. Banyak sampel dalam penelitian ini adalah 319 siswa yang meliputi 108 siswa pada kelas eksperimen 1, 102 siswa pada kelas eksperimen 2, dan 109 siswa pada kelas kontrol.

Penelitian ini menggunakan dua variabel bebas yaitu model pembelajaran dan kecerdasan logis matematis siswa. Satu variabel terikat yaitu prestasi belajar matematika. metode pengumpulan data meliputi metode dokumentasi yang digunakan untuk memperoleh data mengenai kemampuan awal siswa yang diambil dari UAS matematika siswa SMP kelas VII Kabupaten Klaten tahun pelajaran 2014/2015. Data yang diperoleh digunakan untuk mengetahui dan menguji keseimbangan rataan kondisi awal kelompok eksperimen dan kelompok kontrol, metode tes digunakan untuk memperoleh data prestasi belajar pada materi fungsi dan kecerdasan logis matematis siswa. Selanjutnya, uji prasyarat analisis pada penelitian ini menggunakan uji normalitas dengan Lilliefors, uji homogenitas dengan uji Bartlett, uji keseimbangan dengan uji F, sedangkan uji hipotesisnya menggunakan uji anava dua jalan dengan sel tak sama dan dilanjutkan uji komparasi ganda dengan metode Scheffe' jika hipotesis nol ditolak (Budiyono, 2009: 170).

\section{HASIL PENELITIAN DAN PEMBAHASAN}

Hasil uji prasyarat menyimpulkan bahwa semua sampel berasal dari populasi yang berdistribusi normal dan mempunyai variansi yang sama. Setelah uji normalitas dan homogenitas, dilakukan uji keseimbangan menggunakan uji F disajikan pada Tabel 1. 
Tabel 1 Rangkuman Analisis Variansi Satu Jalan dengan Sel Tak Sama

\begin{tabular}{ccccccc}
\hline Sumber & $\mathrm{JK}$ & $\mathrm{dk}$ & $\mathrm{RK}$ & $F_{o b s}$ & $F_{\alpha}$ & Keputusan Uji \\
\hline Populasi & 297,2950 & 2 & 148,6470 & 0,780 & 3,0243 & $H_{0}$ diterima \\
Galat & 60194,1600 & 316 & 190,4880 & - & - & - \\
Total & 60491,4550 & 318 & - & - & - & - \\
\hline
\end{tabular}

Berdasarkan hasil uji keseimbangan terhadap kemampuan awal siswa, , diperoleh $F_{o b s}$ sebesar 0,780 dan $F_{\alpha}$ sebesar 3,0243. Karena $D K=\{F \mid F>3,0243\}$ dan $F_{o b s}<F_{\alpha}$, maka $F_{o b s} \notin \mathrm{DK}$, sehingga $H_{0}$ diterima. Disimpulkan bahwa populasi yang diberi ketiga model mempunyai kemampuan awal yang seimbang atau mempunyai kemampuan awal yang sama.

Selanjutnya dilakukan uji hipotesis menggunakan anava dua jalan dengan sel tak sama. Rangkuman anava dua jalan dengan sel tak sama disajikan pada Tabel 2.

Tabel 2 Rangkuman Analisis Variansi Dua Jalan dengan Sel Tak Sama

\begin{tabular}{crcrccc}
\hline Sumber & \multicolumn{1}{c}{$J K$} & $d k$ & \multicolumn{1}{c}{$R K$} & \multicolumn{1}{c}{$F_{o b s}$} & \multicolumn{1}{c}{$F_{\alpha}$} & Keputusan Uji \\
\hline Model (A) & 8980,6483 & 2 & 4490,3242 & 24,6033 & 3,00 & $H_{O A}$ ditolak \\
KLM (B) & 26741,1226 & 2 & 13370,5613 & 73,2599 & 3,00 & $H_{O B}$ ditolak \\
Interaksi (AB) & 2289,1801 & 4 & 572,2950 & 3,1357 & 2,37 & $H_{O A B}$ ditolak \\
Galat & 56577,6940 & 310 & 182,5087 & - & - & - \\
Total & 94588,6453 & 318 & - & - & - & - \\
\hline
\end{tabular}

Berdasarkan Tabel 1, dapat diperoleh bahwa: (1) terdapat perbedaan prestasi belajar matematika antara siswa yang mendapatkan model pembelajaran TSI, TPS, dan langsung, (2) terdapat perbedaan prestasi belajar matematika antara siswa kecerdasan logis matematis tinggi, sedang, dan rendah, (3) terdapat interaksi antara model pembelajaran dan kecerdasan logis matematis siswa terhadap prestasi belajar matematika siswa.

Rangkuman rerata marginal pada masing-masing model pembelajaran dan kecerdasan logis matematis dapat dilihat pada Tabel 3.

Tabel 3 Rerata Marginal Model Pembelajaran dan Kecerdasan Logis Matematis

\begin{tabular}{lcccc}
\hline \multirow{2}{*}{ Model pembelajaran } & \multicolumn{2}{c}{ Kecerdasan Logis Matematis } & \multirow{2}{*}{ Rerata Marginal } \\
& Tinggi & Sedang & Rendah & \\
\hline TSI & 80.7742 & 68.4000 & 55.4074 & 68.7037 \\
TPS & 69.5238 & 68.6087 & 54.5143 & 63.9608 \\
Langsung & 69.4054 & 55.1250 & 40.8000 & 54.7156 \\
Rerata Marginal & 73.3933 & 65.1563 & 49.3725 & \\
\hline
\end{tabular}

Berdasarkan hasil perhitungan anava diperoleh bahwa $H_{O A}$ ditolak. Oleh karena itu, perlu dilakukan uji komparasi rerata antar baris. Rangkuman hasil uji komparasi ganda antar baris disajikan dalam Tabel 4.

Tabel 4 Rangkuman Hasil Uji Komparasi Ganda Antar Baris

\begin{tabular}{ccccc}
\hline No & $H_{0}$ & $F_{o b s}$ & $2 . F_{0,05: 2: n}$ & Keputusan Uji \\
\hline 1 & $\mu_{1 .}=\mu_{2 .}$ & 6.4657 & 6,000 & $H_{0}$ ditolak \\
2 & $\mu_{1 .}=\mu_{3 .}$ & 58.1601 & 6,000 & $H_{0}$ ditolak \\
3 & $\mu_{2 .}=\mu_{3 .}$ & 24.6770 & 6,000 & $H_{0}$ ditolak \\
\hline
\end{tabular}


Berdasarkan Tabel 3 dan rerata marginal pada Tabel 2, dapat diperoleh bahwa model pembelajaran TSI menghasilkan prestasi belajar yang lebih baik daripada model pembelajaran TPS dan langsung. Model pembelajaran TPS menghasilkan prestasi belajar yang lebih baik daripada model pembelajaran langsung. Hal ini dikarenakan pada model pembelajaran kooperatif tipe TSI memiliki aspek pembelajaran yang sesuai dengan karakteristik matematika dimana siswa tidak hanya sekedar dibiasakan untuk mengetahui dan memahami, akan tetapi juga mengaplikasikan, mensintesis, dan menganalisis suatu masalah seperti dalam proses penemuan ilmiah (Kagan, 1990: 15). Pada model ini siswa terlihat aktif mengkonstruksikan pengetahuannya secara mandiri dengan tanya jawab dan saling menjelaskan melalui diskusi kelompok yang terdiri dari empat anggota secara berpasangan sehingga siswa pada model ini dapat memperoleh pengetahuan secara seimbang dan maksimal. Pada model pembelajaran TPS, siswa juga dikondisikan untuk berdiskusi secara berpasangan dengan menyelesaikan permasalahannya secara mandiri terlebih dahulu, seperti pemberian kesempatan kepada setiap individu untuk menentukan dugaan penyelesaian permasalahan yang mungkin. Akan tetapi, kelompok diskusi pada model ini hanya terdiri dari dua anggota sehingga siswa yang dikenai model pembelajaran ini terbatas dalam menggali informasi dari pasangannya yang berakibat kurang maksimalnya kerjasama antar anggota dalam suatu kelompok. Kemudian untuk model pembelajaran langsung, peran siswa hanya mendengarkan dengan cermat dan mencatat pokok-pokok penting yang dijelaskan guru. Guru mempunyai peranan utama dalam menentukan materi pelajaran. Hal ini mengakibatkan siswa pasif karena tidak ada kegiatan apapun selain mendengarkan penjelasan guru dan mencatat penjelasan guru. Hal ini membuat siswa mudah jenuh dalam mengikuti pembelajaran, sangat tergantung pada guru, dan tidak terlatih untuk belajar mandiri. Akibatnya sesuai dengan temuan penelitian ini, model pembelajaran TSI lebih maksimal dibandingkan dengan model pembelajaran TPS dan model pembelajaran langsung.

Berdasarkan hasil perhitungan anava diperoleh bahawa $H_{0 B}$ ditolak. Oleh karena itu, perlu dilakukan uji komparasi ganda antar kolom. Rangkuman hasil uji komparasi rerata antar kolom disajikan dalam Tabel 5 berikut ini:

\begin{tabular}{ccccc}
\multicolumn{5}{c}{ Tabel 5 Rangkuman Hasil Uji Komparasi Ganda Antar Kolom } \\
\hline No & $H_{0}$ & $F_{o b s}$ & $2 . F_{0,05: 2: n}$ & Keputusan Uji \\
\hline 1 & $\mu_{.1}=\mu_{.2}$ & 19.5162 & 6,000 & $H_{0}$ ditolak \\
2 & $\mu_{.1}=\mu_{.3}$ & 150.2605 & 6,000 & $H_{0}$ ditolak \\
3 & $\mu_{.2}=\mu_{.3}$ & 77.4848 & 6,000 & $H_{0}$ ditolak \\
\hline
\end{tabular}

Berdasarkan Tabel 4 dan rerata marginal pada Tabel 2, dapat diperoleh bahwa siswa kecerdasan logis matematis tinggi mempunyai prestasi belajar yang lebih baik daripada siswa kecerdasan logis matematis sedang dan rendah. Siswa kecerdasan logis 
matematis sedang mempunyai prestasi belajar yang lebih baik daripada siswa kecerdasan logis matematis rendah. Hal ini didukung oleh penelitian yang dilakukan oleh Karisma Ardhi Wijayanto (2013) bahwa siswa dengan kecerdasan logis matematis tinggi mempunyai prestasi belajar matematika yang lebih baik dari pada siswa dengan kecerdasan logis matematis sedang dan rendah. Penelitian yang dilakukan oleh Mohammad et al. (2012) menyatakan bahwa siswa dengan kecerdasan logis matematis rendah yang dikenai model pembelajaran tradisional mempunyai prestasi yang lebih rendah daripada siswa dengan kecerdasan logis matematis yang lebih tinggi.

Berdasarkan hasil perhitungan anava diperoleh bahwa $H_{O A B}$ ditolak. Oleh karena itu, perlu dilakukan uji komparasi rerata antar sel pada baris dan kolom yang sama. Hasil uji komparasi rerata antar sel pada kolom yang sama disajikan dalam Tabel 6.

Tabel 6 Hasil Uji Komparasi Ganda Antar Sel pada Kolom yang Sama

\begin{tabular}{llccc}
\hline & $H_{0}$ & $F_{\text {obs }}$ & $8 . F_{0,05: 8: n}$ & Keputusan Uji \\
\hline a. & $\mu_{11}=\mu_{21}$ & 8.6822 & 15,52 & $\mathrm{H}_{0}$ diterima \\
b. & $\mu_{11}=\mu_{31}$ & 11.9454 & 15,52 & $\mathrm{H}_{0}$ diterima \\
c. & $\mu_{21}=\mu_{31}$ & 0.0010 & 15,52 & $\mathrm{H}_{0}$ diterima \\
d. & $\mu_{12}=\mu_{22}$ & 0.0057 & 15,52 & $\mathrm{H}_{0}$ diterima \\
e. & $\mu_{12}=\mu_{32}$ & 18.8405 & 15,52 & $\mathrm{H}_{0}$ ditolak \\
f. & $\mu_{22}=\mu_{32}$ & 18.7996 & 15,52 & $\mathrm{H}_{0}$ ditolak \\
g. & $\mu_{13}=\mu_{23}$ & 0.0666 & 15,52 & $\mathrm{H}_{0}$ diterima \\
h. & $\mu_{13}=\mu_{33}$ & 18.8457 & 15,52 & $\mathrm{H}_{0}$ ditolak \\
i. & $\mu_{23}=\mu_{33}$ & 19.2367 & 15,52 & $\mathrm{H}_{0}$ ditolak \\
\hline
\end{tabular}

Berdasarkan Tabel 6 dan rerata pada Tabel 3, dapat diperoleh bahwa pada siswa yang mempunyai kecerdasan logis matematis tinggi, yang mendapatkan model pembelajaran TSI memiliki prestasi belajar yang sama baiknya dengan siswa yang mendapatkan model pembelajaran TPS dan model pembelajaran langsung. Hal ini dikarenakan pada siswa yang mempunyai kecerdasan logis matematis tingi memiliki kemampuan yang tinggi dalam menggunakan logika, berpikir, menjawab pertanyaan, mengkonstruksi ide ke dalam ucapan maupun tulisan, dan berdiskusi, sehingga pembelajaran pada siswa yang mempunyai kecerdasan logis matematis tinggi dengan menggunakan model yang berbeda akan menghasilkan prestasi yang sama baiknya.

Pada siswa yang mempunyai kecerdasan logis matematis sedang yang mendapatkan model pembelajaran TSI dan TPS mempunyai prestasi yang sama baiknya. Hal ini dikarenakan pada model pembelajaran TSI siswa yang mempunyai kecerdasan logis matematis sedang pada tahapan tanya jawab secara berpasangan sudah cukup mempunyai kemampuan menjelaskan materi kepada pasangannya dengan baik dikarenakan termotivasi oleh siswa yang mempunyai kecerdasan logis matematis tinggi, sehingga siswa dapat memaksimalkan penalarannya dalam menjelaskan suatu permasalahan kepada pasangannya. Pada model pembelajaran TPS karena hanya terdiri 
dari 2 anggota kelompok, siswa yang mempunyai kecerdasan logis matematis sedang akan lebih termotivasi menyelesaikan permasalahan dengan baik. Karena model pembelajaran TPS dirancang untuk mempengaruhi pola interaksi siswa, siswa dengan kecerdasan logis matematis sedang akan lebih dituntut untuk berdiskusi dan memberikan ide dan mempertimbangkan jawaban yang tepat sebelum disampaikan di depan kelas. Sehingga siswa yang mempunyai kecerdasan logis matematis sedang akan mempunyai prestasi yang sama baiknya degan model pembelajaran TSI maupun TPS. Pada siswa yang mempunyai kecerdasan logis matematis sedang, jika diberikan pembelajaran dengan model pembelajaran tipe TSI dan TPS menghasilkan prestasi lebih baik daripada model pembelajaran langsung. Hal ini dikarenakan tidak adanya tuntutan keaktifan dan tanggungjawab kelompok seperti pada model pembelajaran TSI dan TPS akan menjadikan siswa yang mempunyai kecerdasan logis matematis sedang kurang memiliki semangat belajar dan kurang bisa memaksimalkan penalarannya dalam pemecahan masalah karena proses pembelajaraan yang berpusat pada guru saat dikenai model pembelajaran langsung.

Pada siswa yang mempunyai kecerdasan logis matematis rendah mempunyai prestasi yang sama baiknya dengan model pembelajaran tipe TSI dan TPS dikarenakan pada model pembelajaran TSI siswa yang mempunyai kecerdasan logis matematis rendah pada tahap menyelesaikan masalah secara individu, mereka akan lebih berusaha untuk dapat menyelesaikannya karena dibebani tanggung jawab untuk dapat menjelaskan solusi kepada pasangannya. Pada model pembelajaran TPS siswa yang mempunyai kecerdasan logis matematis rendah mereka akan termotivasi oleh pasangannya untuk memaksimalkan potensi yang dimilikinya untuk menyelesaikan permasalahan karena anggota kelompok hanya terdiri dari 2 orang. Siswa yang mempunyai kecerdasan logis matematis rendah mempunyai prestasi yang sama baiknya apabila dikenai model pembelajaran TSI dan TPS. Pada siswa dengan kecerdasan logis matematis rendah apabila diberikan model pembelajaran TSI akan menghasilkan prestasi yang lebih baik daripada yang diberikan model pembelajaran langsung. Hal ini dikarenakan siswa yang mempunyai kecerdasan logis matematis rendah dalam model pembelajaran TSI mendapat bantuan terhadap kesulitan belajar yang dialami dalam proses tanya jawab berpasangan dan juga akan lebih termotivasi untuk menyelesaikan permasalahan yang dihadapi karena tiap anggota kelompok dibebani tanggung jawab individu untuk dapat menjelaskan solusi permasalahan kepada pasangannya. Siswa yang mempunyai kecerdasan logis matematis rendah pada model pembelajaran TPS juga akan mendapat bantuan ketika proses diskusi secara berpasangan. Pada siswa yang mempunyai kecerdasan logis matematis rendah, dalam model pembelajaran langsung mengalami kesulitan saat menyelesaikan masalah 
karena kurangnya kesempatan untuk berinteraksi dengan siswa lain, sehingga siswa yang mempunyai kecerdasan logis matematis rendah mempunyai prestasi belajar yang rendah pula.

Rangkuman hasil uji komparasi rerata antar sel pada baris yang sama disajikan dalam Tabel 7.

Tabel 7 Hasil Uji Komparasi Ganda Antar Sel pada Baris yang Sama

\begin{tabular}{clccc}
\hline & $H_{0}$ & $F_{\text {obs }}$ & $8 . F_{0,05: 8: n}$ & Keputusan Uji \\
\hline a. & $\mu_{11}=\mu_{12}$ & 16.0545 & 15,52 & $\mathrm{H}_{0}$ ditolak \\
b. & $\mu_{11}=\mu_{13}$ & 50.8797 & 15,52 & $\mathrm{H}_{0}$ ditolak \\
c. & $\mu_{12}=\mu_{13}$ & 16.2163 & 15,52 & $\mathrm{H}_{0}$ ditolak \\
d. & $\mu_{21}=\mu_{22}$ & 0.0662 & 15,52 & $\mathrm{H}_{0}$ diterima \\
e. & $\mu_{21}=\mu_{23}$ & 16.2013 & 15,52 & $\mathrm{H}_{0}$ ditolak \\
f. & $\mu_{22}=\mu_{23}$ & 21.6347 & 15,52 & $\mathrm{H}_{0}$ ditolak \\
g. & $\mu_{31}=\mu_{32}$ & 19.1734 & 15,52 & $\mathrm{H}_{0}$ ditolak \\
h. & $\mu_{31}=\mu_{33}$ & 86.1755 & 15,52 & $\mathrm{H}_{0}$ ditolak \\
i. & $\mu_{32}=\mu_{33}$ & 19.9886 & 15,52 & $\mathrm{H}_{0}$ ditolak \\
\hline
\end{tabular}

Berdasarkan Tabel 7 dan rerata pada Tabel 3, diperoleh bahwa pada model pembelajaran TSI, siswa yang mempunyai kecerdasan logis matematis tinggi mempunyai prestasi belajar yang lebih baik daripada siswa yang mempunyai kecerdasan logis matematis sedang dan rendah. Siswa yang mempunyai kecerdasan logis matematis sedang mempunyai prestasi belajar yang lebih baik daripada siswa yang mempunyai kecerdasan logis matematis rendah. Hal ini sesuai dengan hipotesis penelitian. Hal ini dikarenakan siswa berkecerdasan logis tinggi memiliki kemampuan menalar, mengingat, dan menjawab permasalahan lebih baik, dapat berpikir logis dalam memahami materi dan menyelesaikan setiap permasalahan dengan mudah. Siswa yang mempunyai kecerdasan logis matematis tinggi mempunyai prestasi belajar yang lebih baik daripada siswa yang mempunyai kecerdasan logis matematis sedang. Hal ini dikarenakan siswa yang mempunyai kecerdasan logis matematis sedang di saat memahami permasalahan secara individual kemudian melakukan tanya jawab dengan pasangannya mengalami sedikit kesulitan dibandingkan siswa yang mempunyai kecerdasan logis matematis tinggi. Siswa yang mempunyai kecerdasan logis matematis tinggi mempunyai prestasi belajar yang lebih baik daripada siswa yang mempunyai kecerdasan logis matematis rendah. Hal ini dikarenakan siswa yang mempunyai kecerdasan logis matematis rendah di saat memahami permasalahan secara individual kemudian melakukan tanya jawab dengan pasangannya mengalami banyak kesulitan dibandingkan siswa yang mempunyai kecerdasan logis matematis tinggi. Siswa yang mempunyai kecerdasan logis matematis sedang mempunyai prestasi belajar yang lebih baik daripada siswa yang mempunyai kecerdasan logis matematis rendah. Hal ini dikarenakan siswa yang mempunyai 
kecerdasan logis matematis rendah masih merasa kesulitan dalam memahami materi meskipun sudah dibantu oleh siswa yang memiliki kecerdasan diatasnya karena memiliki penalaran yang rendah dalam memahami materi.

Pada model pembelajaran kooperatif tipe TPS, siswa yang mempunyai kecerdasan logis matematis tinggi dan sedang mempunyai prestasi belajar yang sama baiknya. Hal ini tidak sesuai dengan hipotesis penelitian dikarenakan pada model pembelajaran TPS, siswa dengan kecerdasan logis matematis tinggi lebih bisa menalar, mengingat, menjawab, dan menjelaskan sehingga aktif dan termotivasi untuk membantu teman dengan kecerdasan yang lebih rendah dalam diskusi berpasangan dan siswa dengan kecerdasan logis matematis sedang mendapat bantuan dari siswa yang kecerdasan logis matematisnya lebih tinggi sehingga siswa lebih termotivasi dan lebih paham dengan apa yang sedang dipelajari dalam diskusi berpasangan. Siswa yang mempunyai kecerdasan logis matematis tinggi dan sedang yang diberi model pembelajaran TPS akan mempunyai prestasi belajar yang lebih baik daripada siswa yang mempunyai kecerdasan logis matematis rendah dan telah sesuai dengan hipotesis penelitian. Hal ini dikarenakan pada siswa dengan kecerdasan logis matematis rendah ternyata cenderung pasif dalam proses berpasangan dan diskusi, serta membutuhkan penjelasan ekstra agar dapat memahami suatu materi meskipun sudah diberi bantuan penjelasan dari siswa dengan kecerdasan logis matematis di atasnya. Siswa dengan kecerdasan logis matematis rendah mempunyai prestasi yang lebih jelek daripada siswa dengan kecerdasan logis matematis tinggi dan sedang.

Pada model pembelajaran langsung, siswa yang mempunyai kecerdasan logis matematis tinggi mempunyai prestasi belajar matematika yang lebih baik daripada siswa yang mempunyai kecerdasan logis matematis sedang dan rendah. Siswa yang mempunyai kecerdasan logis matematis sedang mempunyai prestasi belajar matematika yang lebih baik daripada siswa yang mempunyai kecerdasan logis matematis rendah. Hal ini telah sesuai dengan hipotesis penelitian dikarenakan pada model pembelajaran langsung, guru merupakan unsur terpenting dalam proses pembelajaran. Model ini memiliki ciri yaitu guru menyampaikan materi dengan menjelaskan, serta pembagian tugas, dan latihan. Dengan penalaran dan cara berpikir yang baik, siswa yang mempunyai kecerdasan logis matematis tinggi mempunyai prestasi belajar yang lebih baik daripada siswa yang mempunyai kecerdasan logis matematis sedang dan rendah. Siswa yang mempunyai kecerdasan logis matematis sedang mempunyai prestasi belajar yang lebih baik daripada siswa yang mempunyai kecerdasan logis matematis rendah. Hal ini dikarenakan suasana kelas yang cenderung pasif dan membosankan, sehingga siswa yang mempunyai 
kecerdasan logis matematis rendah tidak dapat memahami secara maksimal materi yang disampaikan guru.

\section{SIMPULAN DAN SARAN}

Berdasarkan hasil penelitian dan analisis data yang telah dilakukan, maka dapat disimpulkan bahwa : 1) prestasi belajar matematika siswa yang mendapatkan model pembelajaran TSI lebih baik daripada prestasi belajar matematika siswa yang mendapatkan model pembelajaran TPS dan langsung pada materi fungsi, prestasi belajar matematika pada siswa yang mendapatkan model pembelajaran TPS lebih baik daripada prestasi belajar matematika siswa yang mendapatkan model pembelajaran langsung pada materi fungsi; 2) prestasi belajar matematika siswa yang mempunyai kecerdasan logis matematis tinggi lebih baik daripada prestasi belajar matematika siswa yang mempunyai kecerdasan logis matematis sedang dan rendah pada materi fungsi, dan prestasi belajar matematika siswa yang mempunyai kecerdasan logis matematis sedang lebih baik daripada prestasi belajar matematika siswa yang mempunyai kecerdasan logis matematis rendah pada materi fungsi; 3) pada siswa yang mempunyai kecerdasan logis matematis tinggi, siswa yang mendapatkan model pembelajaran TSI, TPS, dan langsung mempunyai prestasi belajar matematika yang sama pada materi fungsi; pada siswa yang mempunyai kecerdasan logis matematis sedang, siswa yang mendapatkan model pembelajaran TSI mempunyai prestasi belajar matematika yang sama dengan siswa yang mendapatkan model pembelajaran TPS, siswa yang mendapatkan model pembelajaran TSI dan TPS mempunyai prestasi belajar matematika yang lebih baik daripada siswa yang mendapatkan model pembelajaran langsung pada materi fungsi; pada siswa yang mempunyai kecerdasan logis matematis rendah yang mendapatkan model pembelajaran TSI mempunyai prestasi belajar matematika yang sama dengan siswa yang mendapatkan model pembelajaran TPS pada materi fungsi, siswa yang mendapatkan model pembelajaran TSI dan TPS lebih baik daripada siswa yang mendapatkan model pembelajaran langsung pada materi fungsi; 4) pada model pembelajaran TSI, prestasi belajar matematika siswa yang mempunyai kecerdasan logis matematis tinggi lebih baik daripada prestasi belajar matematika siswa yang mempunyai kecerdasan logis matematis sedang, prestasi belajar matematika siswa yang mempunyai kecerdasan logis matematis tinggi dan sedang lebih baik daripada prestasi belajar matematika siswa yang mempunyai kecerdasan logis matematis rendah pada materi fungsi; pada model pembelajaran TPS, prestasi belajar matematika siswa yang mempunyai kecerdasan logis matematis tinggi sama dengan prestasi belajar matematika siswa yang mempunyai kecerdasan logis matematis sedang, prestasi belajar matematika siswa yang mempunyai kecerdasan logis 
matematis tinggi dan sedang lebih baik daripada prestasi belajar matematika siswa yang mempunyai kecerdasan logis matematis rendah pada materi fungsi; pada model pembelajaran langsung, siswa yang mempunyai kecerdasan logis matematis tinggi lebih baik daripada prestasi belajar matematika siswa yang mempunyai kecerdasan logis matematis sedang, prestasi belajar matematika siswa yang mempunyai kecerdasan logis matematis tinggi dan sedang lebih baik daripada prestasi belajar matematika siswa yang mempunyai kecerdasan logis matematis rendah pada materi fungsi.

Berdasarkan simpulan hasil penelitian di atas, penulis dapat memberikan beberapa saran sebagai berikut. 1) Mengacu pada hasil penelitian yang menunjukkan bahwa model pembelajaran TSI menghasilkan prestasi belajar yang lebih baik dibandingkan model pembelajaran TPS dan langsung maka disarankan kepada guru mata pelajaran matematika untuk menggunakan model pembelajaran TSI karena didalam model pembelajaran TSI ini siswa dapat memahami suatu konsep matematika dengan lebih cepat melalui kegiatan tanya jawab secara berpasangan. Pertama satu arah, kemudian mereka bertukar peran sebagai penanya dan penjawab. Siswa juga dapat bertukar informasi dengan penanya tentang apa yang telah mereka pelajari. 2) Sesuai dengan hasil penelitian ini yang menunjukkan bahwa pada masing-masing kategori kecerdasan logis matematis siswa memberikan pengaruh terhadap prestasi belajar matematika siswa, guru diharapkan untuk mengetahui kecerdasan logis matematis siswa. Sehingga guru dapat memilih model pembelajaran yang sesuai dengan karakteristik yang dimiliki siswa agar siswa merasa nyaman dalam pembelajaran di dalam kelas. 3) Sesuai dengan hasil penelitian yang menyatakan bahwa pada siswa dengan kecerdasan logis matematis sedang rendah, yang mendapatkan model pembelajaran TSI dan TPS memiliki prestasi belajar matematika yang lebih baik daripada siswa yang mendapatkan model pembelajaran langsung maka disarankan kepada guru hendaknya menggunakan model pembelajaran TSI atau TPS dalam proses pembelajaran. 4) Sesuai dengan hasil penelitian yang menyatakan bahwa dengan model pembelajaran TSI, TPS, dan langsung siswa dengan kecerdasan logis matematis tinggi dan sedang mempunyai prestasi belajar matematika yang lebih baik daripada siswa dengan kecerdasan logis matematis sedang, maka disarankan kepada guru untuk memperhatikan keberagaman siswa dalam pembagian kelompok belajar, agar setiap kelompok tersebut terdapat siswa dengan kecerdasan logis matematis tinggi atau sedang yang dapat dijadikan sebagai tutor sebaya, agar nantinya setiap kelompok dapat mengikuti proses pembelajaran dengan maksimal.

\section{DAFTAR PUSTAKA}

Budiyono. 2009. Statistika Untuk Penelitian. Surakarta :UNS Press. 
Cheng, H. 2011. A Case Study of Cooperative Learning in Mathematics: Middle School Course Design. Journal of Mathematics Education. Vol. 4. No. 1. 75-88.

Dede, Y. \& Soybas, D. 2011. Preservice Mathematics Teachers' Experiences about Function and Equation Concepts. Eurasia Journal of Mathematics and Technology Education. Vol. 7. No. 2. 89-102.

E.T Ruseffendi. 1991. Pengantar Kepada Membantu Guru Mengembangkan Kompetensinya dalam Pengajaran Matematika Untuk Meningkatkan CBSA. Bandung: Tarsito.

Gardner, H. 2010. Multiple Intelligence. www.howardgardner.com

Kagan, S. 1990. Cooperative Learning: The Structural Approach. Newport Beach, CA: Kagan

Karisma Ardhi Wijayanto. 2013. Eksperimentasi Model Pembelajaran Kooperatif Teams Tournament (TGT) dan Team Assisted Individualization (TAI) pada Materi KPK dan FPB Ditinjau dari Tingkat Kecerdasan Logika Matematika. Tesis, Surakarta: UNS. Tidak Dipublikasikan.

Koppenhaver, G.D. \& Shrader, C.B. 2003. Structuring The Classrooms for Performance: Cooperative Learning With Instructor-Assigned Teams. Decision Sciences Journal of Innovative Education. Vol. 1. No. 1. 1-21.

Liang, T. 2002. Implementing Cooperative Learning In EFL Theacing: Process and Effects. A Thesis For The Degree of Doctor of Philosophy, National Taiwan Normal University.

Mohammad, N., Gholamreza H.H.N., and Mahmoud, H. 2012. The Effect of Gardner Theory Application on Mathematical/Logical Intelligence and Student's Mathematical Functioning Relationship. Journa Procedia - Social and Behavioral Sciences. No. 47. 2169 - 2175.

Nini Subini. 2012. Psikologi Pembelajaran. Sleman: Mentari Pusaka.

Suparman. 2001. Guided Speaking: Practiced Guide to Speak English. UII Press: Yogjakarta.

Walmsley, L. E. A. \& Muniz, J. 2003. Connecting Research to Teaching: Cooperative Learning and Its Effect in A High School Geometry Classroom. The National Council of Teachers of Mathematics. Vol. 96. No. 2. 112-116.

Zakaria, E., Chin, C.L. \& Daud, Y. 2010. The Effect of Cooperative Learning on Students' Mathematics Achievement and Attitude towards Mathematics. Journal of Social Sciences. Vol. 6. No. 2. 272-275. 